\title{
Proces odnowy organizacyjnej polskich przedsiębiorstw w świetle badań*
}

\section{The process of organizational renewal of Polish enterprises based on the research}

\author{
Łukasz Wawrzynek \\ Uniwersytet Ekonomiczny we Wrocławiu, e-mail: lukasz.wawrzynek@ue.wroc.pl
}

\begin{abstract}
Streszczenie
Artykuł prezentuje analizę badań obrazujących procesy odnowy organizacyjnej polskich przedsiębiorstw. Badania obejmowały działające na terenie Polski przedsiębiorstwa, które, zgodnie z przyjętą definicją odnowy organizacyjnej, zidentyfikowały u siebie występowanie w latach 2008-2012 elementów niniejszych procesów. Zespół realizujący badania postawił sobie dwa podstawowe problemy badawcze do weryfikacji na podstawie przeprowadzonych badań. Pierwsze związane było z identyfikacją elementów inicjujących procesy odnowy organizacyjnej, a drugie z elementami wewnętrznej koordynacji procesów odnowy mających wpływ na poziom jej efektywności.
\end{abstract}

Słowa kluczowe: zmiana organizacyjna, odnowa organizacyjna, doskonalenie.

\section{Abstract}

The paper presents an analysis of the results of research showing the organizational renewal processes of Polish companies. The studies included enterprises functioning in Poland, which according to the definition of organizational renewal, identified these elements of processes in 2008-2012. The team that conducted research has set itself two main research problems to review on the basis of the research. The first was related to the identification of the elements initiating organizational renewal processes, and the other was related to the elements of internal coordination of renewal processes affecting the level of its effectiveness.

Keywords: organizational change, organizational renewal, improvement.

* Opracowanie na podstawie prac realizowanych w ramach projektu badawczego pt.: „Odnowa organizacyjna polskich przedsiębiorstw” nr N N 115 080039, finansowanego ze środków Narodowego Centrum Nauki. 


\section{Wstęp}

Wyzwania związane z utrzymaniem przewagi konkurencyjnej nie dotyczą już dziś wyłącznie poszukiwania nowych strategii funkcjonalnych przez przedsiębiorstwa, ale w świetle stawianych przez rynek wyzwań konieczne jest szersze spojrzenie na wewnętrzne programy zmian. Konieczne jest otwarcie się na nowy sposób działania i osiągnięcie stawianych przed organizacjami celów, którymi są w dalszej perspektywie przede wszystkim osiąganie wysokiego poziomu wydajności organizacyjnej, a w końcu długoterminowe przetrwanie. Procesy organizowania się (kształtowania) przedsiębiorstwa i strategiczna odnowa są istotne dla długoterminowego przetrwania i osiągania dobrej koniunktury organizacji [Augier, Teece 2009, s. 410]. Dla autorów realizowanego projektu badawczego jednym ze sposobów nowego spojrzenia na organizację i nowy sposób realizacji walki konkurencyjnej jest właśnie odnowa organizacyjna, która stała się przedmiotem badań w ramach prac badawczych nad polskimi przedsiębiorstwami. Dlatego też warto podjąć odpowiednie działania mające na celu wyszukanie i wykorzystanie tych składowych organizacji, które z jednej strony stanowią o tożsamości organizacji, a z drugiej dają podstawę do utrzymania bądź osiągnięcia konkurencyjnej pozycji na rynku [Wawrzynek 2012, s. 157].

\section{Odnowa organizacyjna jako przedmiot badań}

Brak jednoznacznego zdefiniowania pojęcia odnowy organizacyjnej kieruje nasze rozważania na działania organizacji, które mają jej zapewnić, na dziś i na przyszłość, adekwatne do wymagań rynku i możliwe reakcje. Odnowa organizacyjna w rozumieniu strategicznego procesu odnowy przebiega w organizacjach w systematycznych fazach, które łączą w sobie indywidualne działania, ustalając nowy porządek procesu, i pozwolą uzasadnić zarówno bieżące, jak i przyszłe (kierunki) działania przedsiębiorstwa [Peltola 2012, s. 49].

Odnowa organizacyjna, przez zespół realizujący badania w ramach projektu badawczego pt.: „Odnowa organizacyjna polskich przedsiębiorstw”, definiowana jest jako „treść, proces i efekt przekształceń kluczowych elementów systemu zarządzania warunkowanego zmianami modelu biznesowego" [Bełz 2012, s. 19; Cyfert, Bełz, Wawrzynek 2014, s. 16; Bełz, Krzemiński 2014, s. 11].

Zgodnie z modelem odnowy organizacyjnej, badania opierają się na analizie trzech warstw organizacji: definicyjnej, regulacyjnej i realizacyjnej. Warstwa definicyjna zawiera definicje wzorca rozwoju organizacji oparte głównie na modelu biznesu. Warstwa regulacyjna zawiera zestaw regulacji i struktur, narzędzi i praktyk oraz wartości i celów systemu zarządzania. I na koniec warstwa realizacyjna - opiera się na procesach realnych, operacyjnych przedsiębiorstwa [Wawrzynek 2012, s. 157]. Model odnowy analizowany jest $\mathrm{z}$ dwóch perspektyw. Pierwsza to perspektywa przyczyn, czy, inaczej mówiąc, przesłanek procesów odnowy organizacyjnej. Druga natomiast jest ściśle związana z sytuacją organizacji i jej otoczenia oraz ze sposobem przeprowadzenia procesu odnowy organizacyjnej w kontekście uzyskiwanych rezultatów tych zmian mierzonych poziomem wskazywanej efektywności.

\section{Założenia badawcze i próba badawcza}

Postępowanie realizowane $\mathrm{w}$ ramach programu badawczego związanego z identyfikacją przyczyn oraz diagnozy sposobu wykorzystywania procesów odnowy organizacyjnej w polskich przedsiębiorstwach prowadzone jest drogą badań ankietowych. Sam proces badań składał się z dwóch podstawowych etapów. Pierwszym etapem było skierowanie ankiet do 500 przedsiębiorstw. W tym kroku uzyskano 146 zwrotnych ankiet w okresie 06-07.2013, które po weryfikacji zmniejszono do 126 ankiet. Weryfikacje wskazań z ankiet pierwszego etapu skłoniły zespół do zawężenia liczby pytań oraz ograniczenia skali możliwych odpowiedzi.

W wyniku drugiego etapu badań w okresie od października 2013 roku do kwietnia 2014 roku uzyskano ostatecznie kolejne 347 wypełnionych i zweryfikowanych kwestionariuszy ankietowych, co w badaniu dało sumaryczną liczbę 473 poprawnie wypełnionych ankiet, które stały się podstawą dalszych analiz w ramach realizowanych badań. Wskazania i wyniki badania pierwszego etapu są tożsame z wynikami, jakie uzyskano w ramach etapu drugiego, co pozwoliło potwierdzić wyniki wstępnych analiz.

Wśród ankietowanych było 215 przedsiębiorstw z udziałem kapitału zagranicznego oraz 258 przedsiębiorstw z deklarowanym wyłącznie polskim kapitałem. 155 przedsiębiorstw zadeklarowała liczbę zatrudnionych na stałe pracowników pomiędzy 10 a 49, 189 zadeklarowało zatrudnienie na poziomie

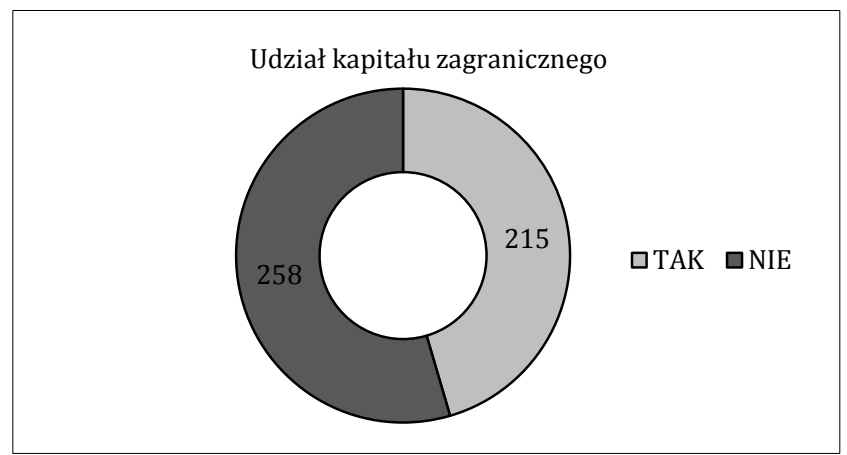

Rysunek 1. Struktura ankietowanych przedsięborstw - udział kapitału zagranicznego

Źródło: opracowanie własne na podstawie przeprowadzonych badań.

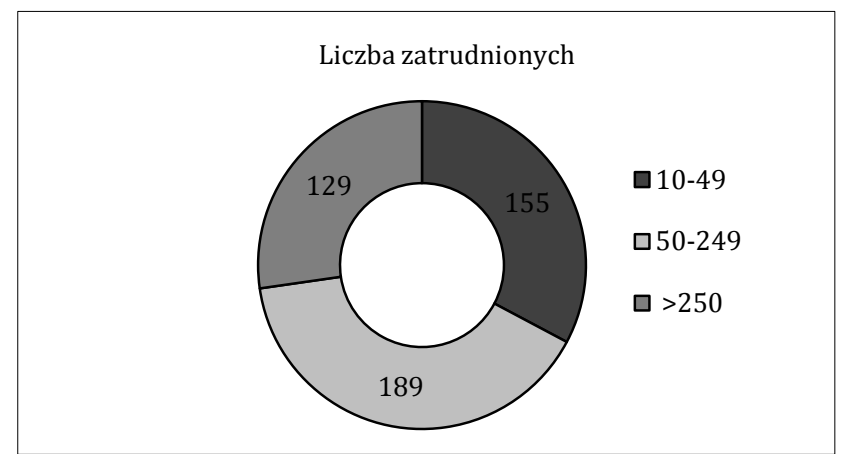

Rysunek 2. Struktura ankietowanych przedsięborstw - liczba zatrudnionych

Źródło: opracowanie własne na podstawie przeprowadzonych badań. 


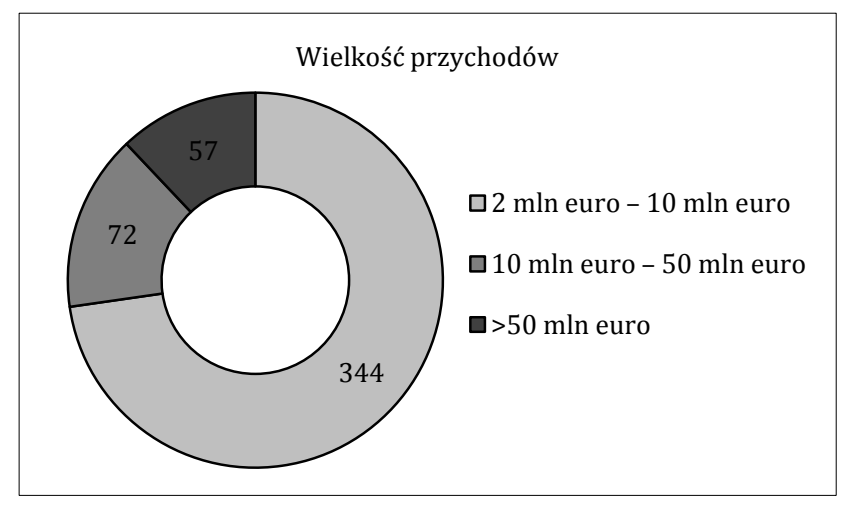

Rysunek 3. Struktura ankietowanych przedsięborstw - wielkość przychodów

Źródło: opracowanie własne na podstawie przeprowadzonych badań.

od 50 do 249 osób, a 129 zadeklarowało zatrudnienie na poziomie przekraczającym 250 pracowników. Gros z ankietowanych przedsiębiorców, bo aż 344, zadeklarowało przychód na poziomie pomiędzy 2 a $10 \mathrm{mln}$ euro. 72 ankietowanych wskazało na przychody w przedziale pomiędzy 10 a $50 \mathrm{mln}$ euro, a zaledwie 57 ankietowanych zadeklarowało przychody powyżej 50 mln euro rocznie.

Strukturę ankietowanych w zakresie udziału kapitału zagranicznego, liczby zatrudnionych oraz przychodów rocznych ilustrują rys. 1-3.

\section{Podstawowe wyniki i obserwacje}

Zespół realizujący badania miał na celu zidentyfikowanie zależności występujących w obu perspektywach realizowanych badań w powiązaniu z sytuacjami osiągania najwyższej efek- tywności w zakresie procesów odnowy organizacyjnej. Założenie to dotyczyło zarówno przesłanek samego podjęcia procesu odnowy, jak i jego realizacji. Analiza podstawowa wykazała, że dane zbierane w metryczce ankiety nie były różnicujące. Oznacza to, że nie zaobserwowano zależności pomiędzy rodzajem zainwestowanego kapitału, wielkością zatrudnienia czy poziomem przychodu a wpływem któregokolwiek z tych kryteriów na uzyskiwanie przez badane przedsiębiorstwa wyższego poziomu efektywności w stosunku do pozostałych grup badanych firm. Analiza wpływu otoczenia organizacji na osiąganie wyższego poziomu efektywności została już szerzej zaprezentowana we wcześniejszych opracowaniach ${ }^{1}$.

Założenia o istnieniu innych czynników, determinujących osiąganie wyższej efektywności w procesach odnowy organizacyjnej, nakazały skupić się w dalszych analizach na wcześniej wyodrębnionych dwóch perspektywach i ich składnikach.

Zebrane dane ankietowe są analizowane w większości przy użyciu testów chi-kwadrat $\mathrm{w}$ związku $\mathrm{z}$ ich charakterem (zmienne skategoryzowane). W niektórych tylko przypadkach występuje możliwość badania zależności pomiędzy zmiennymi przy wykorzystaniu adekwatnego współczynnika korelacji.

\section{Perspektywa przesłanek}

Efektywność procesów zmian wynika nie tylko ze sposobu realizacji procesu odnowy, lecz także z sytuacji, w jakiej znajduje się organizacja, podejmując decyzję o zainicjowaniu procesu. W ramach identyfikacji zależności osiągania wyższego poziomu efektywności realizowanych procesów odnowy, w ramach prowadzonego postępowania badawczego zidentyfikowano i poddano analizie kilkanaście przesłanek podjęcia wskazanych procesów. Procentowe ujęcie wskazań poszczególnych przesłanek podjęcia procesu odnowy prezentuje rys. 4 .

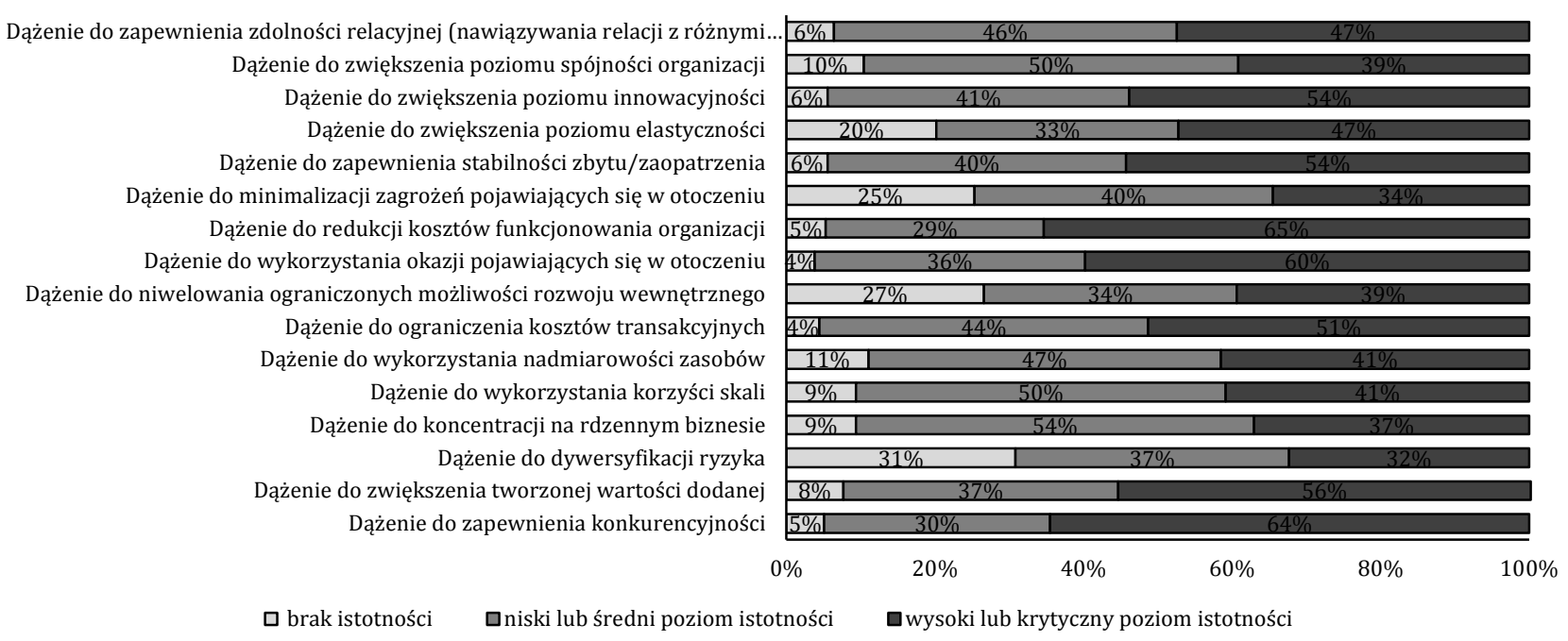

Rysunek 4. Struktura wskazań przesłanek podejmowania procesu odnowy

Źródło: opracowanie własne na podstawie przeprowadzonych badań.

${ }^{1}$ Szerzej na temat zależności pomiędzy poziomem burzliwości otoczenia a uzyskiwanymi poziomami wyższej efektywności procesów zmian organizacyjnych w opracowaniu [Cyfert, Bełz, Wawrzynek 2014]. 
Wartościami granicznymi, jakie uzyskiwały wskazania przesłanek podejmowania procesu odnowy na poziomie wysokim lub krytycznie istotnym, jest poziom $60 \%$ i więcej. Wskazania takie uzyskały przesłanki dążenia do redukcji kosztów funkcjonowania organizacji, dążenia do wykorzystywania okazji pojawiających się w otoczeniu oraz dążenia do zapewnienia konkurencyjności.

Dążenie do zapewnienia konkurencyjności jest najbardziej jednoznaczne oraz bezpośrednio i najsilniej powiązane z samym procesem odnowy organizacyjnej. Rozumiane jest jako podstawowa właściwość procesu odnowy, związana zarówno z walką konkurencyjną, jak i z brakiem możliwości podnoszenia swojego poziomu konkurencyjności przy zachowaniu dotychczasowego sposobu działania organizacji. W wyniku analizy postawionej hipotezy alternatywnej, iż stawianie przez organizację na poziomie wysokim i krytycznym dążenia do zapewnienia konkurencyjności jako przesłanki do podjęcia procesu odnowy wpływa na osiąganie wyższego poziomu efektywności w stosunku do hipotezy zerowej, iż nie ma zależności pomiędzy poziomem istotności wskazań tej przesłanki, dowiedziono, że należy odrzucić hipotezę zerową i przyjąć alternatywną. Analiza dała tym samym potwierdzenie, iż przedsiębiorstwa, które podejmują proces odnowy organizacyjnej w wyniku dążenia do zapewnienia konkurencyjności jako przesłanki o wysokiej ważności lub o krytycznym znaczeniu wpływa na osiąganie wyższego poziomu efektywności prowadzonych procesów odnowy organizacyjnej. Wyniki analizy prezentuje tab. 1.

Tabela 1. Test hipotezy o braku zależności pomiędzy dążeniem do zapewnienia konkurencyjności jako przesłanki do podjęcia procesu odnowy a poziomem efektywności procesu odnowy

Expected counts are printed below observed counts Chi-Square contributions are printed below expected counts

$$
\begin{aligned}
& \begin{array}{rrrrr}
1 & 2 & 3 & \text { Total } \\
13 & 22 & 29 & 64 \\
3,27 & 19,47 & 41,26 & \\
28,980 & 0,328 & 3,643 &
\end{array} \\
& \begin{array}{lllll}
2 & 36 & 225 & 469 & 730
\end{array} \\
& 37,28 \quad 222,11 \quad 470,62 \\
& 0,044 \quad 0,038 \quad 0,006 \\
& \begin{array}{lllll}
3 & 47 & 325 & 714 & 1086
\end{array} \\
& 55,46 \quad 330,42 \quad 700,12 \\
& 1,289 \quad 0,089 \quad 0,275 \\
& \text { Total } 9657212121880 \\
& \text { Chi-Sq }=34,691 ; \mathrm{DF}=4 ; \mathrm{P}-\text { Value }=0,000
\end{aligned}
$$

Źródło: opracowanie własne na podstawie przeprowadzonych badań - obliczenia Minitab.

Z perspektywy wyniku wskazującego na istnienie wskazanej zależności, patrząc nieco szerzej na samo zagadnienie szukania nowych obszarów konkurencyjności, można wyprowadzić spostrzeżenie o istocie procesu odnowy organizacyjnej jako nowe- go obszaru poszukiwania i uzyskiwania czy też zapewniania konkurencyjności przedsiębiorstw.

Drugą przesłanką, wskazywaną przez ankietowanych jako element wysokiego bądź krytycznego poziomu istotności przy podejmowaniu procesów odnowy, jest dążenie do wykorzystywania okazji pojawiających się $\mathbf{w}$ otoczeniu. Z punktu widzenia definicji procesu odnowy, przesłanka ta wydaje się ściśle korespondować z konstruktem, jakim jest odnowa organizacyjna. Można zauważyć powiązanie $\mathrm{z}$ mechanizmem redefiniowania modelu biznesu przy równoczesnym uwzględnieniu elementów systemu zarządzania, wykorzystując do operacyjnego przełożenia nowej konstrukcji założeń działania przedsiębiorstwa procesów, które mają być odpowiedzialne za operacyjne odzwierciedlenie założeń modelu biznesu. Analizowana była hipoteza zerowa o braku związku pomiędzy dążeniem do wykorzystywania okazji pojawiających się $\mathrm{w}$ otoczeniu jako przesłanki procesów odnowy a poziomem efektywności tych procesów względem hipotezy alternatywnej, zakładającej istnienie zależności pomiędzy wysokim poziomem ważności tejże przesłanki do podejmowania procesu odnowy a uzyskiwaniem wysokiego poziomu efektywności procesów odnowy organizacyjnej. W wyniku postępowania dowiedziono nieprawdziwości stawianej hipotezy zerowej i konieczności przyjęcia hipotezy alternatywnej. Wyniki analizy prezentuje tab. 2.

Tabela 2. Test hipotezy o braku zależności pomiędzy dążeniem do wykorzystywania okazji pojawiających się w otoczeniu jako przesłanki do podjęcia procesu odnowy a poziomem efektywności procesu odnowy

Expected counts are printed below observed counts Chi-Square contributions are printed below expected counts

$$
\begin{aligned}
& \begin{array}{rrrrr}
1 & 2 & 3 & \text { Total } \\
12 & 14 & 38 & 64 \\
2,45 & 23,29 & 38,26 & \\
37,201 & 3,703 & 0,002 &
\end{array} \\
& \begin{array}{lllll}
2 & 21 & 283 & 426 & 730
\end{array} \\
& 27,96 \quad 265,60 \quad 436,45 \\
& 1,731 \quad 1,140 \quad 0,250 \\
& \begin{array}{lllll}
3 & 39 & 387 & 660 & 1086
\end{array} \\
& 41,59 \quad 395,12 \quad 649,29 \\
& 0,161 \quad 0,167 \quad 0,177 \\
& \text { Total } 72 \quad 684 \quad 1124 \quad 1880 \\
& \text { Chi-Sq }=44,532 ; \mathrm{DF}=4 ; \mathrm{P}-\text { Value }=0,000
\end{aligned}
$$

Źródło: opracowanie własne na podstawie przeprowadzonych badań - obliczenia Minitab.

Trzecią przesłanką, wskazywaną przez ankietowane przedsiębiorstwa na poziomie $65 \%$, jest zagadnienie, jak ważne lub krytycznie ważne jest dążenie do redukcji kosztów funkcjonowania organizacji. Osiąganie wyższego poziomu konkurencyjności poprzez uzyskiwanie wyższej efektywności operacyjnej, a tym samym obniżania funkcjonowania organizacji, 
jest wynikiem nasilania się walki konkurencyjnej i wysokiej dynamiki zmian w zakresie poszukiwania nowych źródeł przewagi wśród konkurentów. Hipotezą przyjętą w tym zakresie w ramach postępowania badawczego był brak zależności pomiędzy wskazywaniem dążenia do redukcji kosztów funkcjonowania organizacji jako ważnej lub krytycznej przesłanki a uzyskiwaniem wysokiego poziomu efektywności procesu odnowy. Hipotezą alternatywną było powiązanie uzyskiwania wysokiego poziomu efektywności procesów odnowy tych organizacji, które wskazywały jako ważną lub krytyczną przesłankę do podjęcia procesów odnowy jako dążenie do redukcji kosztów funkcjonowania organizacji. Postępowanie badawcze, przeprowadzone na bazie danych z badań ankietowych, nakazało odrzucić hipotezę zerową, a przyjąć alternatywną, dowodząc istnienia zależności występowania wysokiego poziomu efektywności procesów odnowy w przypadku ich podjęcia na podstawie przesłanki redukcji kosztów. Wynik analizy prezentuje tab. 3

Tabela 3. Test hipotezy o braku zależności pomiędzy dążeniem do redukcji kosztów funkcjonowania organizacji jako przesłanki do podjęcia procesu odnowy a poziomem efektywności procesu odnowy

Expected counts are printed below observed counts Chi-Square contributions are printed below expected counts

$$
\begin{aligned}
& \begin{array}{rrrrr}
1 & 2 & 3 & \text { Total } \\
13 & 16 & 35 & 64 \\
& 3,40 & 18,79 & 41,80 & \\
27,048 & 0,415 & 1,107 &
\end{array} \\
& \begin{array}{lllll}
2 & 27 & 253 & 450 & 730
\end{array} \\
& 38,83 \quad 214,34 \quad 476,83 \\
& 3,604 \quad 6,973 \quad 1,510 \\
& \begin{array}{lllll}
3 & 60 & 283 & 743 & 1086
\end{array} \\
& 57,77 \quad 318,87 \quad 709,37 \\
& 0,086 \quad 4,035 \quad 1,595
\end{aligned}
$$

Źródło: opracowanie własne na podstawie przeprowadzonych badań - obliczenia Minitab.

Mówiąc o konkurencyjności organizacji, w sposób naturalny w dzisiejszych czasach, zwłaszcza w Europie, myśli się o efektywności na poziomie operacyjnym, czyli efektywności realizacji procesów oraz o innowacyjności. Co prawda, dążenie do zwiększenia poziomu innowacyjności uzyskało w wyniku zbieranych danych poniżej $60 \%$ głosów dla wskazań jej jako ważnej lub krytycznej przesłanki, jednak sama innowacyjność wpisuje się w naturalny sposób w ogólne trendy dzisiejszego nurtu zarządzania. Weryfikując hipotezę powiązań występowania przesłanek na poziomie wysokim lub krytycznym z wysokim poziomem efektywności, również w przypadku testowania hipotezy o istnieniu zależności wysokiego lub krytycznego poziomu przesłanki do podejmowania procesów odnowy, jaką jest dążenie do innowacyjności z osiąganiem wyższego poziomu efektywności samych procesów odnowy organizacyjnej, w wyniku przeprowadzonego postępowania badawczego wskazano, iż taka zależność występuje.

Wskazane, w ramach badań ankietowych, pozostałe dwanaście przesłanek związanych z kierunkami dążeń organizacji jako przesłanek do podejmowania procesów odnowy organizacyjnej, w ramach przeprowadzonego postępowania badawczego nie wykazało zależności pomiędzy ich wyższym lub krytycznym poziomem występowania a wyższym poziomem efektywności uzyskiwanym przez organizacje procesów odnowy organizacyjnej. Zatem możemy je uznać za nieistotne w ramach badań obszaru konstrukcji modelu procesu odnowy organizacyjnej.

\section{Perspektywa realizacji procesu odnowy}

Sposób ukształtowania i realizacji procesu odnowy organizacyjnej, szczególnie gdy podejmowany jest jako szansa na przebudowę biznesu i związany z poszukiwaniem możliwości na poprawę konkurencyjności organizacji, powinien być nastawiony szczególnie na osiąganie możliwie najwyższego poziomu jego efektywności.

Przebadane kilkadziesiąt cech procesu odnowy organizacyjnej może dać nam odpowiedź na pytanie o modelowe ujęcie procesu odnowy, jeśli spojrzeć nań pod kątem uzyskiwania przez organizacje wyników definiowanych jako efektywne.

W ramach badań zajmowano się dwoma głównymi aspektami oddziaływania badanych czynników na końcowy efekt realizowanej odnowy organizacyjnej. Wzięto pod uwagę zarówno czas, w jakim dane czynniki oddziałują na organizację w całości procesu odnowy, jak i siłę ich natężenia występującą w ramach procesu.

W badaniach skupiono się zwłaszcza na dziewięciu elementach, które zostały w ramach badań wstępnych zidentyfikowane jako mające największy możliwy wpływ na osiąganie wysokiego poziomu efektywności procesów odnowy organizacyjnej. Elementy te do celów badań nazwano następująco:

1) identyfikacja procesów zmian w otoczeniu,

2) wybór modelu zmian,

3) zmiana i dostosowanie realizowanego modelu biznesowego,

4) kreowanie wizji przełomu i inspirowanie pracowników,

5) mobilizowanie i zmiana postaw pracowników,

6) dopasowywanie kultury organizacyjnej,

7) pozyskiwanie i zabezpieczenie zasobów,

8) transformacja i dostosowanie modelu organizacyjnego,

9) standaryzacja i ekonomiczna optymalizacja.

W ramach przeprowadzonych badań określono, że większość analizowanych elementów występujących w trakcie realizacji procesu odnowy organizacyjnej, której efekty wiązały się z wysoką wydajnością procesu, występowała w ramach pierwszych dwóch części czasu, w jakim zachodziły procesy odnowy organizacyjnej. Kilka z nich występowało w trakcie niemal całego procesu odnowy. Zależności występowania badanych elementów, wskazanych powyżej, powiązanych z wysoką oceną efektu procesu odnowy, prezentuje rys. 5 . 
czas oddziaływania elementu

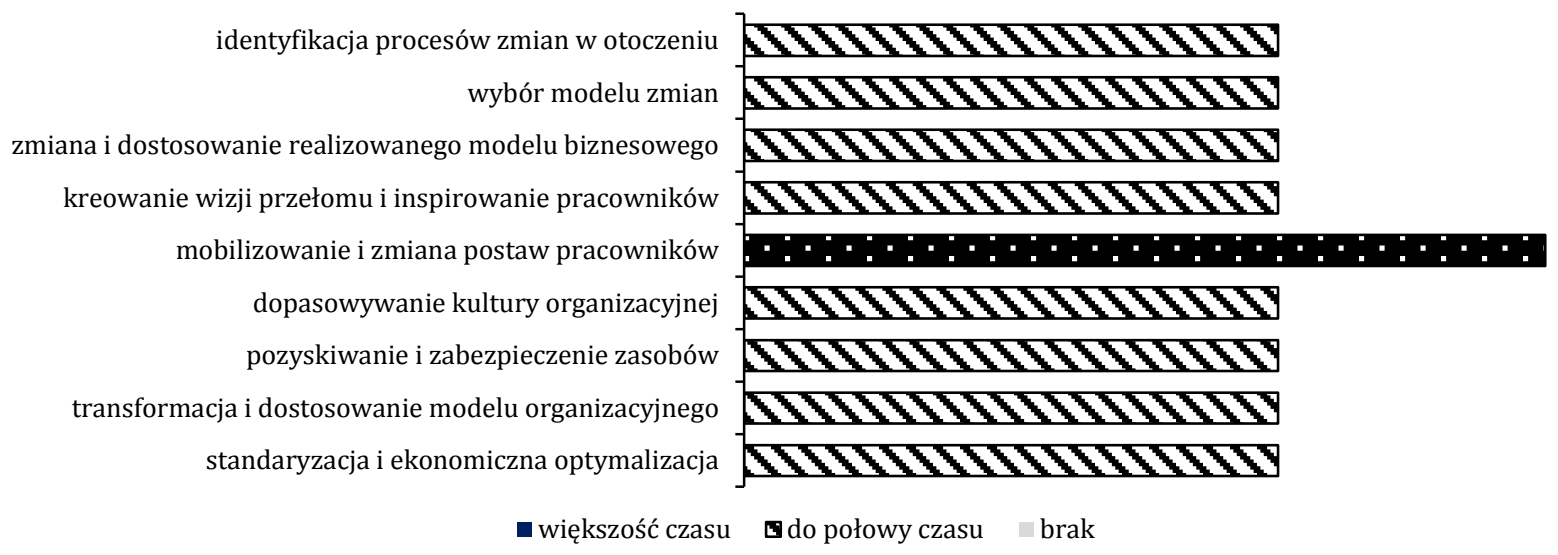

Rysunek 5. Czas występowania badanych elementów w ramach procesu odnowy organizacyjnej dla wysokiej efektywności procesu

Źródło: opracowanie własne na podstawie przeprowadzonych badań.

Badanie wskazuje, że wszystkie wskazane elementy są istotne w procesie odnowy organizacyjnej dla osiągania wysokiego poziomu jej efektywności. Każdy z nich powinien występować co najmniej przez połowę trwania procesu odnowy. Jedynie czynnik określony jako „mobilizowanie i zmiana postaw pracowników", który oddaje istotę zmian behawioralnych ludzi $\mathrm{w}$ organizacji, powinien występować $\mathrm{w}$ większości trwania procesu odnowy organizacyjnej, by osiągała ona wysoki poziom efektywności.

W badaniach identyfikowano również poziom natężenia wskazanych czynników, które wpływają na wysoki poziom osiąganej efektywności procesu odnowy organizacyjnej. Można było wykazać istnienie zależności w 7 na 9 analizowanych elementów. Dla elementów „kreowanie wizji przełomu i inspirowanie pracowników” oraz dla elementu „pozyskiwanie i zabezpieczenie zasobów" nie można było wykazać istnienia zależności pomiędzy poziomem ich natężenia a wysokim poziomem osiąganej efektywności procesu odnowy organizacyjnej.
Zależności pomiędzy poziomem natężenia badanych elementów a wysokim poziomem efektywności badanych procesów odnowy organizacyjnej prezentuje rys. 6 .

Dwa z badanych elementów, „mobilizowanie i zmiana postaw pracowników” i „standaryzacja i ekonomiczna optymalizacja”, których poziom natężenia występowania w ramach badanych procesów odnowy organizacyjnej był wysoki, są powiązane, a w połączeniu ze stawianą hipotezą wpływają na osiąganie wysokiego poziomu efektywności procesu odnowy. Pozostałe badane elementy tj.: „identyfikacja procesów zmian w otoczeniu”, „wybór modelu zmian”, „zmiana i dostosowanie realizowanego modelu biznesowego", „dopasowywanie kultury organizacyjnej” i „transformacja i dostosowanie modelu organizacyjnego" wykazują istnienie zależności ich występowania na słabym lub średnim poziomie, co wpływa na osiąganie przez organizację wysokiego poziomu efektywności procesu odnowy organizacyjnej.

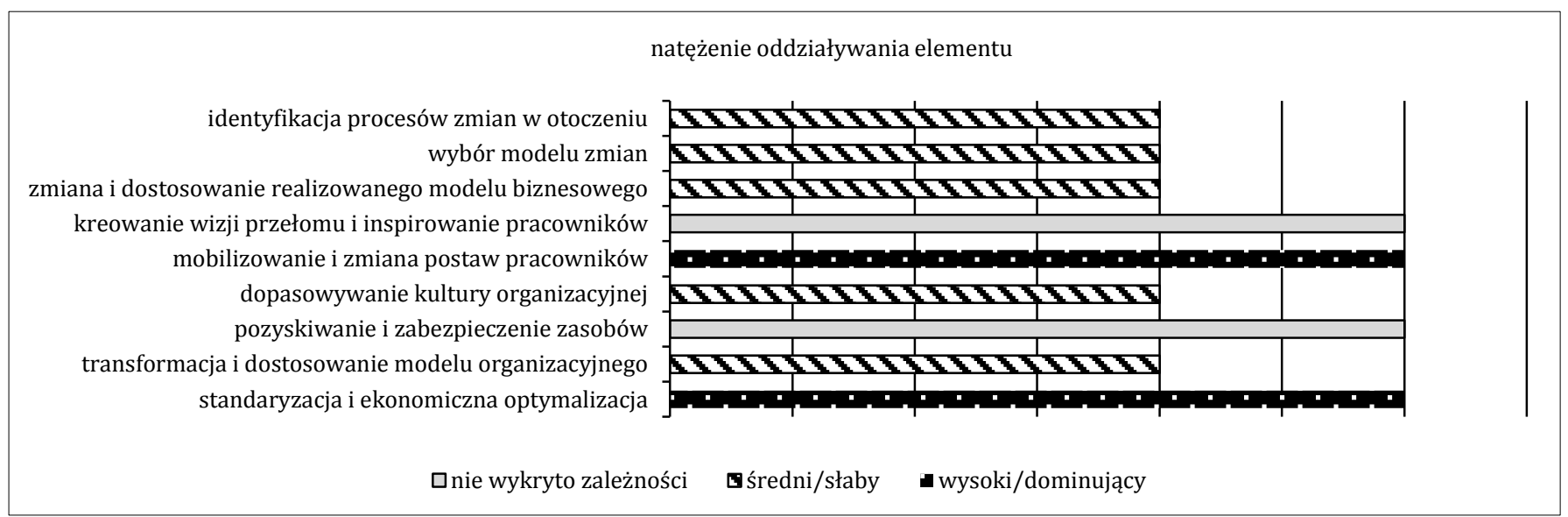

Rysunek 6. Poziom natężenia badanych elementów w ramach procesu odnowy organizacyjnej dla wysokiej efektywności procesu

Źródło: opracowanie własne na podstawie przeprowadzonych badań. 
Należy zatem, bazując na uzyskanych rezultatach badań, przy planowaniu procesu odnowy organizacyjnej, a jeszcze bardziej przy jego realizacji, zwrócić uwagę na wszystkie badane elementy. Jednak szczególnie istotne będzie dopasowanie czasu ich oddziaływania w procesie zmian i poziomu siły natężenia, by poprzez odpowiednie, wskazane powyżej, proponowane poziomy dla odpowiednich czynników nie przeinwestowywać ani nie zaniedbywać żadnego z nich, by proces odnowy organizacyjnej mógł osiągać możliwie najwyższy poziom efektywności.

\section{Podsumowanie}

W zrealizowanych badaniach stawiano sobie za cel m.in. identyfikację elementów inicjujących procesy odnowy organizacyjnej, a także identyfikację elementów wewnętrznej koordynacji procesów odnowy mających wpływ na poziom jej efektywności, ze szczególnym uwzględnieniem układu jednych i drugich $\mathrm{w}$ powiązaniu z uzyskiwaniem wysokiego poziomu efektywności zmian.

Opierając się zatem na badaniach, należy przyjąć, że wysoki poziom efektywności procesów odnowy organizacyjnej uzyskują organizacje, których motywacja do podjęcia działań w zakresie odnowy organizacyjnej jest oparta zwłaszcza na dążeniu do zapewnienia konkurencyjności, do wykorzystywania okazji pojawiających się w otoczeniu oraz do redukcji kosztów funkcjonowania. W ramach samej realizacji procesu odnowy należy zadbać o istnienie wszystkich dziewięciu analizowanych elementów, mając szczególnie na uwadze występo- wanie ich przynajmniej przez połowę czasu trwania procesu, z wyjątkiem mobilizowania i zmiany postaw pracowników, które powinny trwać przez większość czasu realizacji procesu odnowy, i to na wysokim poziomie natężenia, tak samo jak i na wysokim poziomie natężenia, przynajmniej przez połowę czasu trwania procesu odnowy, powinien występować element związany z identyfikacją możliwych szans i zagrożeń.

Tak realizowany proces odnowy organizacyjnej powinien przynieść wysoki poziom efektywności.

\section{Literatura}

Augier M., Teece D.J., 2009, Dynamic capabilities and the role of managers in business strategy and economic performance, Organization Science, vol. 20, no 2 (March-April).

Bełz G, 2012, Potencjał dostosowawczy w procesach odnowy przedsiębiorstw, Przegląd Organizacji, nr 11.

Cyfert Sz., Bełz G, Wawrzynek Ł., 2014, Wpływ burzliwości otoczenia na efektywność procesów odnowy organizacyjnej, Organizacja i Kierowanie, $\mathrm{nr}$ 1A (159).

Bełz G., Krzemiński A., 2014, Zarządcze struktury sieciowe w procesie odnowy przedsiębiorstw, Marketing i Rynek, nr 5.

Peltola S., 2012, Can an old firm learn new tricks? A corporate entrepreneurship approach to organizational renewal, Business Horizons, vol. 55.

Wawrzynek Ł., 2012, System zarzadzania $w$ procesie odnowy organizacyjnej, [w:] Strategie i mechanizmy odnowy przedsiębiorstw, red. G. Bełz, Sz. Cyfert, Wydawnictwo Uniwersytetu Ekonomicznego we Wrocławiu, Wrocław. 